PNL-10771

UC-350

\title{
Cost Effectiveness of the 1993 Model Energy Code in New Jersey
}

\author{
R. G. Lucas
}

September 1995

Prepared for

the U.S. Department of Energy

under Contract DE-AC06-76RLO 1830

Pacific Northwest Laboratory

Richland, Washington 99352 



\section{DISCLAIMER}

Portions of this document may be illegible in electronic image products. Images are produced from the best available original document. 


\section{Summary}

This report documents an analysis of the cost effectiveness of the Council of American Building Officials' 1993 Model Energy Code (MEC) building thermal-envelope requirements for single-family houses and multifamily housing units in New Jersey. The goal was to compare the cost effectiveness of the $1993 \mathrm{MEC}$ to the alternate allowed in the 1993 Building Officials \& Code Administrators $\left(\mathrm{BOCA}^{\oplus}\right)$ National Energy Conservation Code--American Society of Heating, Refrigerating, and Air-Conditioning Engineers (ASHRAE) Standard 90A-1980--based on a comparison of the costs and benefits associated with complying with each. This comparison was performed for four cities representing the range of New Jersey climates--Camden, New Brunswick, Somerville, and Sparta.

The analysis was done for two different scenarios: a "move-up" home buyer purchasing a single-family house and a "first-time" financially limited home buyer purchasing a multifamily unit. For the single-family home buyer, compliance with the 1993 MEC was estimated to increase first costs by $\$ 1028$ to $\$ 1564$, resulting in an incremental down payment increase of $\$ 206$ to $\$ 313$ (at 20\% down). The time when the homeowner realizes net cash savings (i.e., net positive cash flow) for houses built in accordance with the $1993 \mathrm{MEC}$ was from 1 to 5 years. That is, the home buyer who paid $20 \%$ down had recovered increases in down payments and mortgage payments in energy cost savings by the end of the fifth year or sooner and thereafter will save more money each year.

For the multifamily unit home buyer, compliance with the 1993 MEC is much less expensive. First costs were estimated to increase by $\$ 121$ to $\$ 223$, resulting in an incremental down payment increase of $\$ 12$ to $\$ 22$ (at $10 \%$ down). The time when the homeowner realizes net cash savings (i.e., net positive cash flow) for houses built in accordance with the 1993 MEC was 1 to 3 years. 


\section{Contents}

Summary $\ldots \ldots \ldots \ldots \ldots \ldots \ldots \ldots \ldots \ldots \ldots \ldots \ldots \ldots \ldots \ldots \ldots$

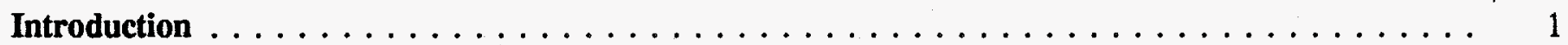

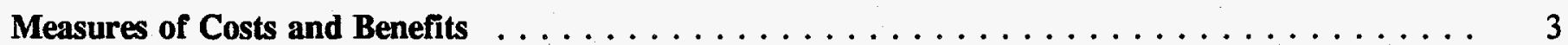

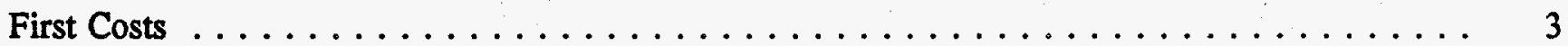

Mortgages: Down Payment, Monthly Payment, and Tax Deductions . . . . . . . . . . . 4

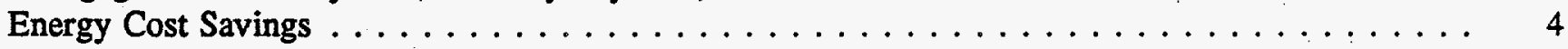

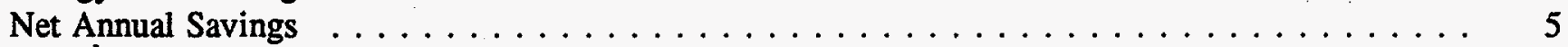

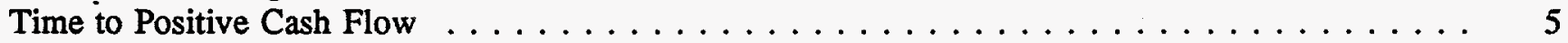

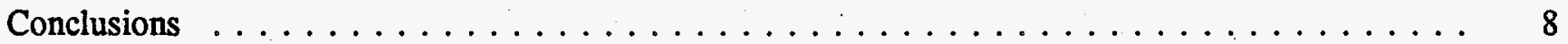

Analysis Tool $\ldots \ldots \ldots \ldots \ldots \ldots \ldots \ldots \ldots \ldots \ldots \ldots \ldots \ldots \ldots$

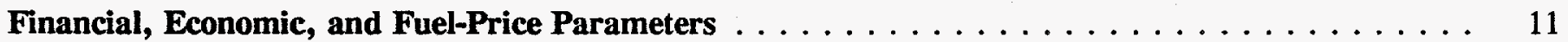

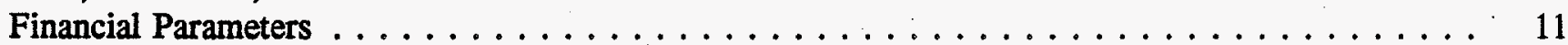

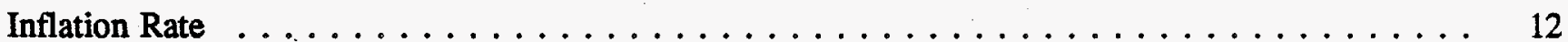

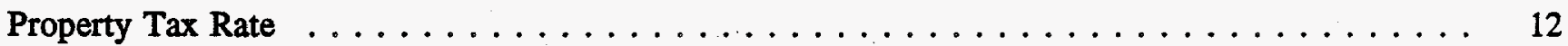

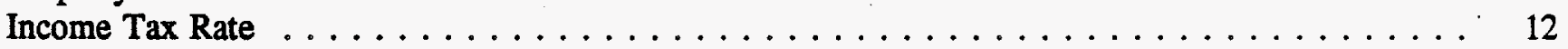

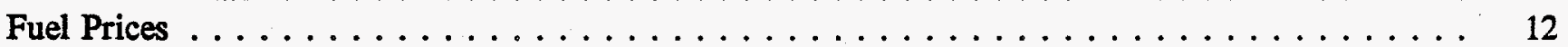

Energy-Efriciency Measures $\ldots \ldots \ldots \ldots \ldots \ldots \ldots \ldots \ldots \ldots \ldots$

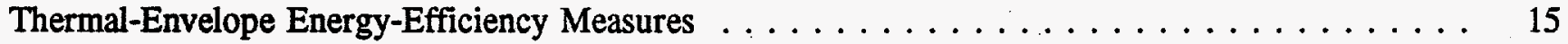

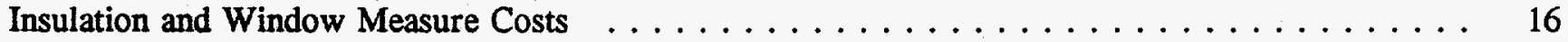

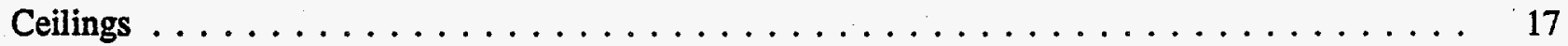

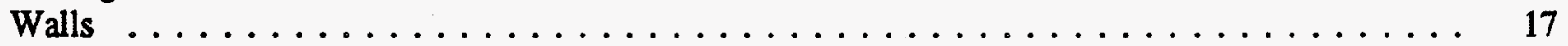

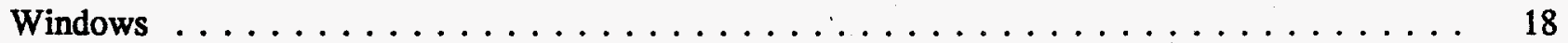

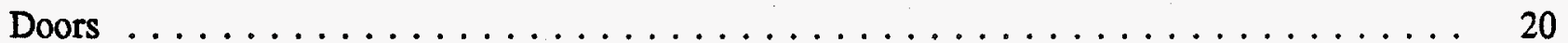

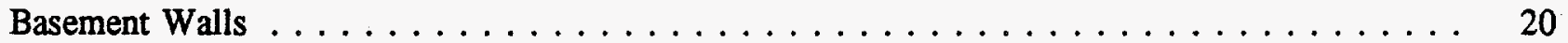

Prototype Dwellings . . . . . . . . . . . . . . . . . . . . . . . . . . 21

Heating, Ventilating, and Air-Conditioning Specifications . . . . . . . . . . . . 22

Distribution System Efficiency . . . . . . . . . . . . . . . . . . . . . . . . . 22

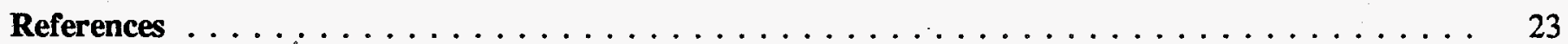




\section{Figures}

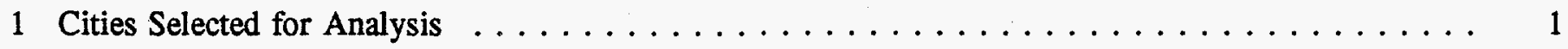

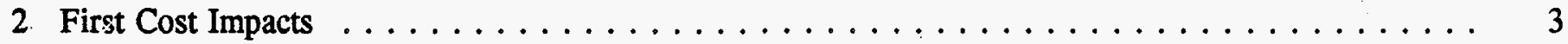

3 Typical Cash Flow for the First Owner of a Single-Family House $\ldots \ldots \ldots \ldots \ldots \ldots$

\section{Tables}

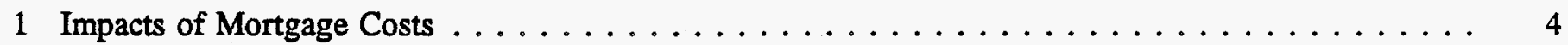

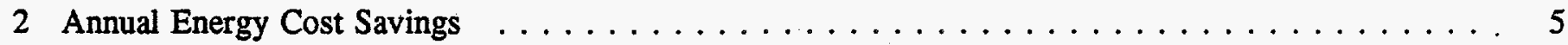

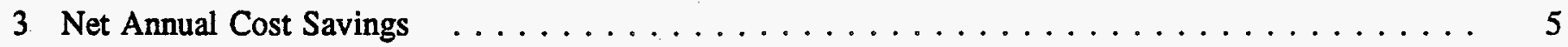

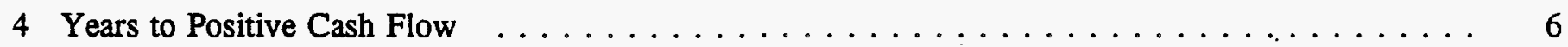

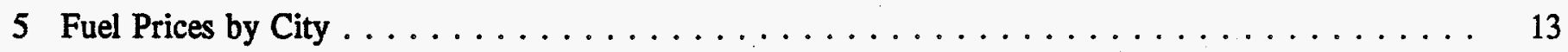

6 Energy-Efficiency Measures for ASHRAE Standard 90A-1980 and 1993 MEC . . . . . . . 16

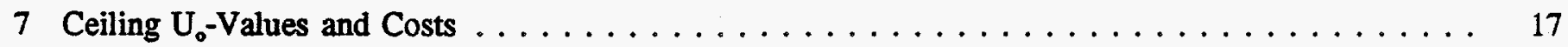

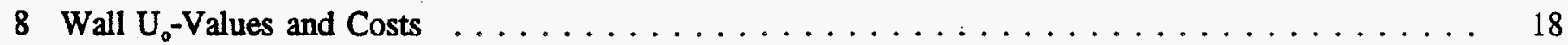

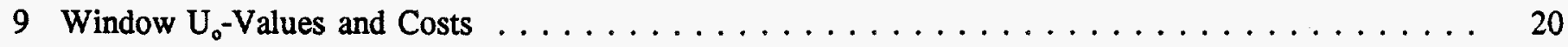

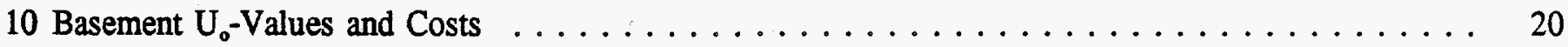

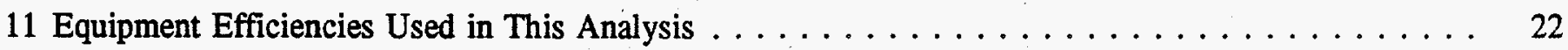




\section{Introduction}

This report documents the analysis of the cost effectiveness, in the state of New Jersey, of the Council of American Building Officials' 1993 Model Energy Code (MEC) (CABO 1993) building thermal-envelope requirements for new construction. This analysis was directed by the U.S. Department of Energy's (DOE) Energy Efficiency and Renewable Energy Department (Christine Ervin, Assistant Secretary) and was conducted by Pacific Northwest Laboratory. ${ }^{(2)}$

This analysis examined the costs and benefits associated with installing the insulation and windows needed to comply with the requirements of the 1993 MEC. These costs and benefits to the homeowner result from the increases in construction and financing costs and savings in energy costs. The analysis was done for two different scenarios: a "move-up" home buyer purchasing a single-family house and a "first-time" financially limited home buyer purchasing a smaller multifamily unit.

Four New Jersey cities were selected for this analysis (Figure 1). These four cities were selected to highlight the range of climates in New Jersey and the corresponding MEC requirements. The MEC thermal-envelope requirements are a function of heating degree-days (HDDs), a measure of heating season severity. The cities presented here and in the remainder of

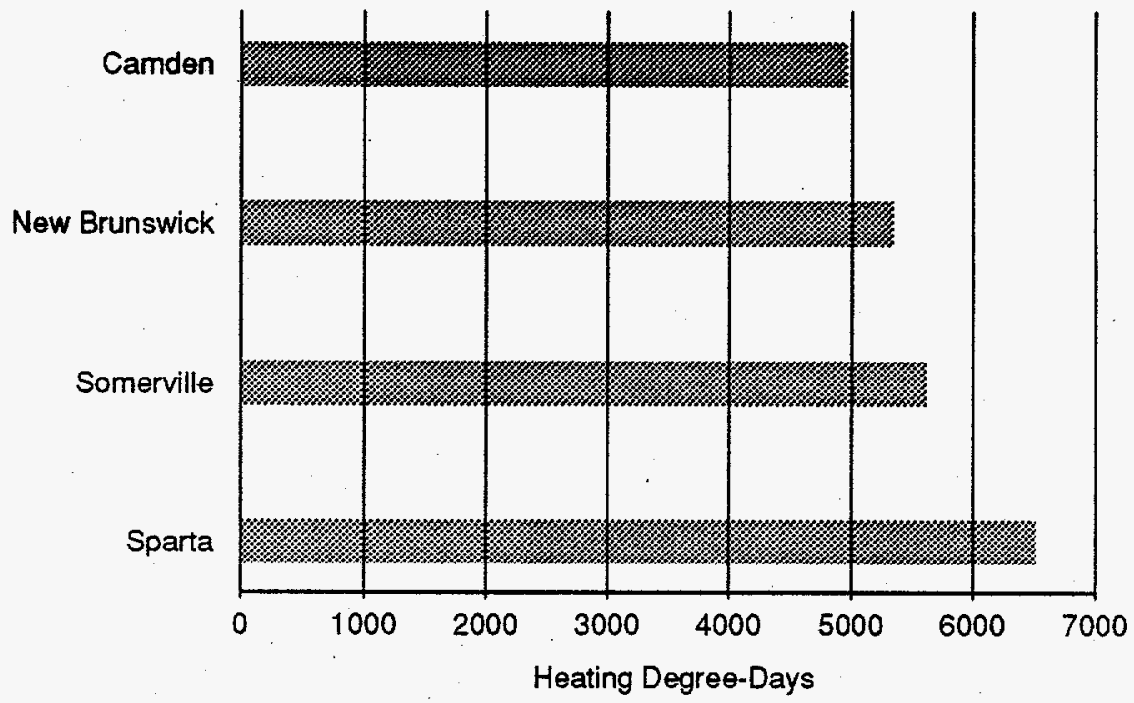

Figure 1. Cities Selected for Analysis

(a) Pacific Northwest Laboratory is a multiprogram national laboratory operated for the U.S. Department of Energy under Contract DE-AC06-76RLO 1830 by Battelle Memorial Institute. 
the report are in order of mildest (Camden) to coldest (Sparta) location. Figure 1 shows the HDDs for each of the four cities; however, HDDs for nearby Philadelphia, Pennsylvania were used for Camden and HDDs for nearby Newton, New Jersey were used for Sparta.

This report is organized as follows. The results of the costs and benefits measures, including the estimated impacts of the 1993 MEC on homeowners in New Jersey, are given in the next section. A discussion of the choice of the financial, economic, and fuel-price parameters used in the analysis of costs and benefits follows. The energy-efficiency measures typically used to comply with the Building Officials \& Code Administrators (BOCA $\left.{ }^{\circ}\right)$ National Energy Conservation Code (BOCA 1993) and the 1993 $\mathrm{MEC}$, their characteristics, and costs are given. The references cited in the . text are presented at the end of this report. 


\section{Measures of Costs and Benefits}

First Costs

This section presents the findings of the cost/benefit analysis of increasing insulation levels and improving windows in New Jersey dwellings to the levels necessary to comply with the $1993 \mathrm{MEC}$. The overall results are shown in terms of first cost, mortgage cost impacts, energy cost impacts, and the years to cumulative positive cash flow. All results reported here are economic impacts from the perspective of the home buyer/owner. It is important to stress this report analyzed the incremental costs and benefits resulting from increasing energy-efficiency levels from the levels needed for compliance with the American Society of Heating, Refrigerating, and AirConditioning Engineers (ASHRAE) Standard 90A-1980 (ASHRAE 1980) to the levels needed for compliance with the $1993 \mathrm{MEC}$.

The first cost is the incremental retail cost to purchase and install energy features in the house; for example, the cost to buy and install more insulation. This cost includes the builder's profit. This is the cost that would be paid if the dwelling were paid for in cash.

Figure 2 compares the increase in first costs (assuming no mortgage) from the construction changes needed for compliance with the 1993 MEC for both the single-family and the multifamily home buyer. The MEC will increase first costs more in colder locations because the code is more stringent in these locations. Much of the first cost increase from the MEC for the single-family home buyer is attributable to the addition of basementwall insulation. The first cost increase for the multifamily home buyer is low because the envelope requirements for multifamily buildings in the MEC are less stringent than those for single-family houses, and only minor changes are needed for compliance.

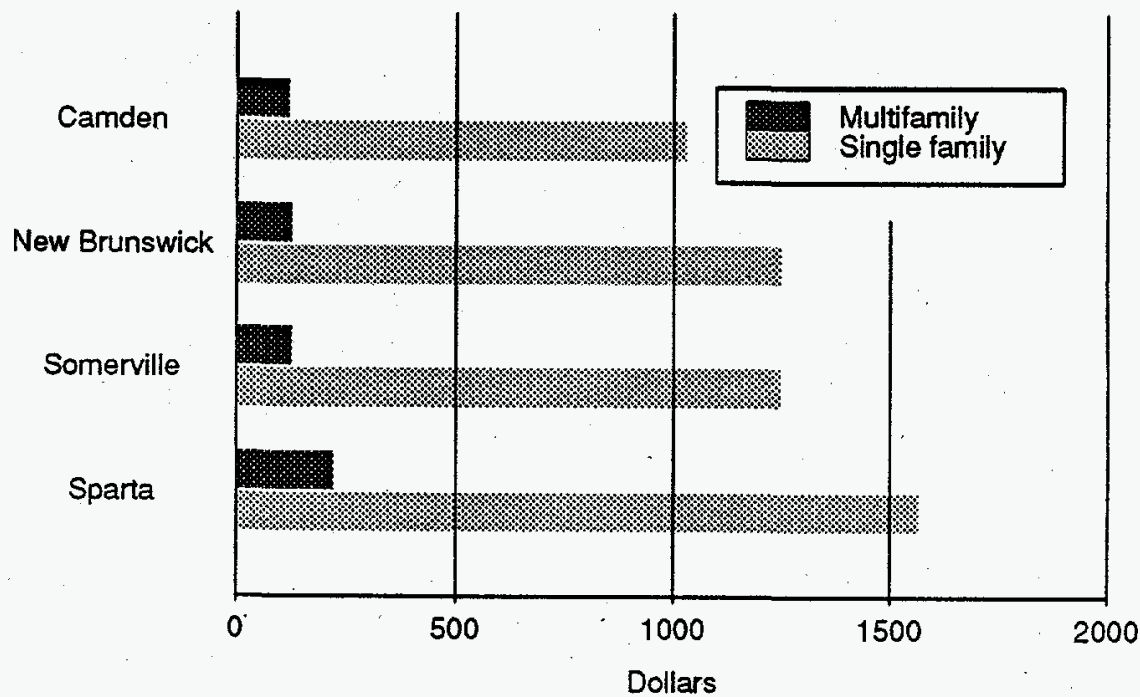

Figure 2. First Cost Impacts 


\section{Mortgages: Down \\ Payment, Monthly \\ Payment, and Tax \\ Deductions}

Because most houses are financed, the financial impacts of the 1993 MEC on mortgages will likely be of significant interest to the consumer. This report deals with a single-family home buyer making a down payment of $20 \%$ of the loan amount and a more financially limited multifamily home buyer making a down payment of $10 \%$ of the loan amount. Mortgage payments are constant over the period of the mortgage, and the interest portion of the payments is assumed to be deducted from income taxes. An adjustable-rate mortgage might result in different costs to the home buyer, but this type of mortgage is not examined here because of its unpredictable nature.

Table 1 shows how mortgage-related costs will be impacted for a 30-year fixed-rate mortgage. The up-front costs include the down payment, points, and loan fees. The savings from income tax deductions of the mortgage interest will slowly decrease over time, and the values shown in Table 1 are for the first year.

Table 1. Impacts of Mortgage Costs

\begin{tabular}{||l|c|c|c|c||}
\hline & \multicolumn{3}{|c|}{ Cost Change Per Housing Unit } \\
\cline { 2 - 5 } & Camden & $\begin{array}{c}\text { New } \\
\text { Brunswick }\end{array}$ & Somerville & Sparta \\
\hline \hline Annual mortgage payment increase & $\$ 76$ & $\$ 92$ & $\$ 92$ & $\$ 115$ \\
$\quad \begin{array}{l}\text { Single family } \\
\text { Multifamily }\end{array}$ & $\$ 10$ & $\$ 10$ & $\$ 11$ & $\$ 18$ \\
\hline Down payment increase & $\$ 217$ & $\$ 264$ & $\$ 263$ & $\$ 330$ \\
Single family & $\$ 14$ & $\$ 14$ & $\$ 14$ & $\$ 25$ \\
$\quad$ Multifamily & $\$ 20$ & $\$ 24$ & $\$ 24$ & $\$ 30$ \\
\hline First year tax deduction savings & $\$ 2$ & $\$ 2$ & $\$ 2$ & $\$ 3$ \\
$\quad$ Single family \\
Multifamily & & & & \\
\hline
\end{tabular}

\section{Energy Cost Savings}

A reduction in the energy costs (i.e., the homeowner's utility bill for heating and cooling) is the major benefit of any energy-efficiency standard. The intent of the $1993 \mathrm{MEC}$ is to "enable effective use of energy in new building construction" (CABO 1993). The MEC has requirements that are intended to keep energy use (and thereby energy costs) to a reasonably low level.

Table 2 shows the estimated energy cost savings by heating fuel/equipment type resulting from the increased level of energy efficiency required by the MEC. Energy cost savings are approximately equal for natural gas and oil and considerably higher for electric heat pumps. As might be expected, the energy cost savings from the MEC are larger in the colder climates than in the milder climates. Because compliance with the MEC for multifamily . 
Table 2. Annual Energy Cost Savings

\begin{tabular}{||l|l|c|c|c|c|}
\hline & \multicolumn{5}{|c|}{ Cost Change Per Housing Unit } \\
\cline { 2 - 6 } & $\begin{array}{c}\text { Heating } \\
\text { Fuel Type }\end{array}$ & Camden & $\begin{array}{c}\text { New } \\
\text { Brunswick }\end{array}$ & Somerville & Sparta \\
\hline \hline Single family & Natural gas & $\$ 121$ & $\$ 136$ & $\$ 149$ & $\$ 247$ \\
& Oil & $\$ 122$ & $\$ 137$ & $\$ 151$ & $\$ 247$ \\
& Heat pump & $\$ 212$ & $\$ 243$ & $\$ 266$ & $\$ 454$ \\
\hline Multifamily & Natural gas & $\$ 17$ & $\$ 18$ & $\$ 20$ & $\$ 29$ \\
& Oil & $\$ 17$ & $\$ 18$ & $\$ 20$ & $\$ 30$ \\
& Heat pump & $\$ 26$ & $\$ 28$ & $\$ 33$ & $\$ 51$ \\
\hline
\end{tabular}

buildings requires only minor changes, the energy cost savings are relatively low.

It should be noted that the annual energy cost savings in Table 2 are for the initial fuel prices. The energy cost savings are expected to increase in the future because energy prices are expected to rise. Most of the energy cost savings are from heating season energy savings.

Net Annual Savings

Table 3 shows the net annual savings, including energy costs, mortgage payments, property tax, and mortgage tax deduction, but not including the up-front costs.

Table 3. Net Annual Cost Savings

\begin{tabular}{||l|l|c|c|c|c|}
\hline & \multicolumn{5}{|c|}{ Cost Change Per Housing Unit } \\
\cline { 2 - 6 } & \multicolumn{1}{|c|}{$\begin{array}{c}\text { Heating } \\
\text { Fuel Type }\end{array}$} & Camden & $\begin{array}{c}\text { New } \\
\text { Brunswick }\end{array}$ & Somerville & Sparta \\
\hline \hline Single family & Natural gas & $\$ 53$ & $\$ 53$ & $\$ 66$ & $\$ 143$ \\
& Oil & $\$ 54$ & $\$ 54$ & $\$ 68$ & $\$ 142$ \\
& Heat pump & $\$ 142$ & $\$ 159$ & $\$ 182$ & $\$ 348$ \\
\hline Multifamily & Natural gas & $\$ 6$ & $\$ 8$ & $\$ 9$ & $\$ 11$ \\
& Oil & $\$ 7$ & $\$ 7$ & $\$ 9$ & $\$ 12$ \\
& Heat pump & $\$ 16$ & $\$ 18$ & $\$ 22$ & $\$ 32$ \\
\hline
\end{tabular}

Time to Positive Cash Flow

Most consumers want to know when they will start saving money (accounting for all costs and benefits). The energy cost savings resulting from increased energy efficiency start as soon as the dwelling is occupied. Of more interest may be the time when the consumer has saved more money than he or she has paid out (including the down payment). This is referred to as the time to positive cash flow. Beyond this time, the net cost savings can be expected to continue to grow; thus, the shorter the length of 
time to positive cash flow, the more attractive investing in increased energy efficiency becomes.

Table 4 shows the number of years until the homeowner realizes a net cost savings from the increased levels of energy efficiency (i.e., the cumulative savings exceeds the cumulative expenditures). This length of time was derived from the calculation of the up-front costs, mortgage payments, energy costs, property tax, and mortgage interest tax deductions. For example, during the fourth year of ownership, a single-family homeowner in Camden with natural gas heat would have saved more money than expended, and the savings would continue to grow after that time. Note that positive cash flow starts in 5 years or less in all cases.

Table 4. Years to Positive Cash Flow

\begin{tabular}{||l|l|c|c|c|c||}
\hline \multirow{2}{*}{} & \multicolumn{5}{|c|}{ Cost Change Per Housing Unit } \\
\cline { 2 - 6 } & $\begin{array}{c}\text { Heating } \\
\text { Fuel Type }\end{array}$ & Camden & $\begin{array}{c}\text { New } \\
\text { Brunswick }\end{array}$ & Somerville & Sparta \\
\hline \hline Single family & Natural gas & 4 & 5 & 4 & 3 \\
& Oil & 4 & 5 & 4 & 3 \\
& Heat pump & 2 & 2 & 2 & 1 \\
\hline Multifamily & Natural gas & 3 & 2 & 2 & 3 \\
& Oil & 3 & 3 & 2 & 3 \\
& Heat pump & 1 & 1 & 1 & 1 \\
\hline
\end{tabular}

A simple method of looking at the costs and benefits of higher energy efficiency over time is by analyzing the cash flow. Figure 3 shows the cumulative cash flow for a typical first owner of a single-family house in New Brunswick with natural gas heating. The figure shows the cash flow for a dwelling built to the efficiency levels required by the $1993 \mathrm{MEC}$ relative to a dwelling built to comply with ASHRAE Standard 90A-1980. A 30 -year mortgage and a $20 \%$ down payment were assumed. Lines with annual changes in property taxes and mortgage deductions are not shown on the plot but are included in the total savings. The owner is assumed to sell the house after 7 years, at which time the mortgage is terminated. At the time of the purchase, there is a cost of $\$ 264$ to cover the increased down payment and other up-front cost increases. Because the energy cost savings exceed the mortgage payment increases, the net cash flow for each year is positive (excluding the first year, which has the up-front costs). At the end of 7 years when the house is sold, the estimated resale value exceeds the mortgage termination cost related to the additional investment in energy efficiency by $\$ 125$, so the total savings increases from $\$ 206$ to $\$ 331$. The resale value is based on uninflated straight-line depreciation. The cumulative cash flow becomes positive early in the fifth year and continues to grow in all future years. Note that if the first owner sells the house in the future, any future owner will also quickly obtain a positive cash flow. 


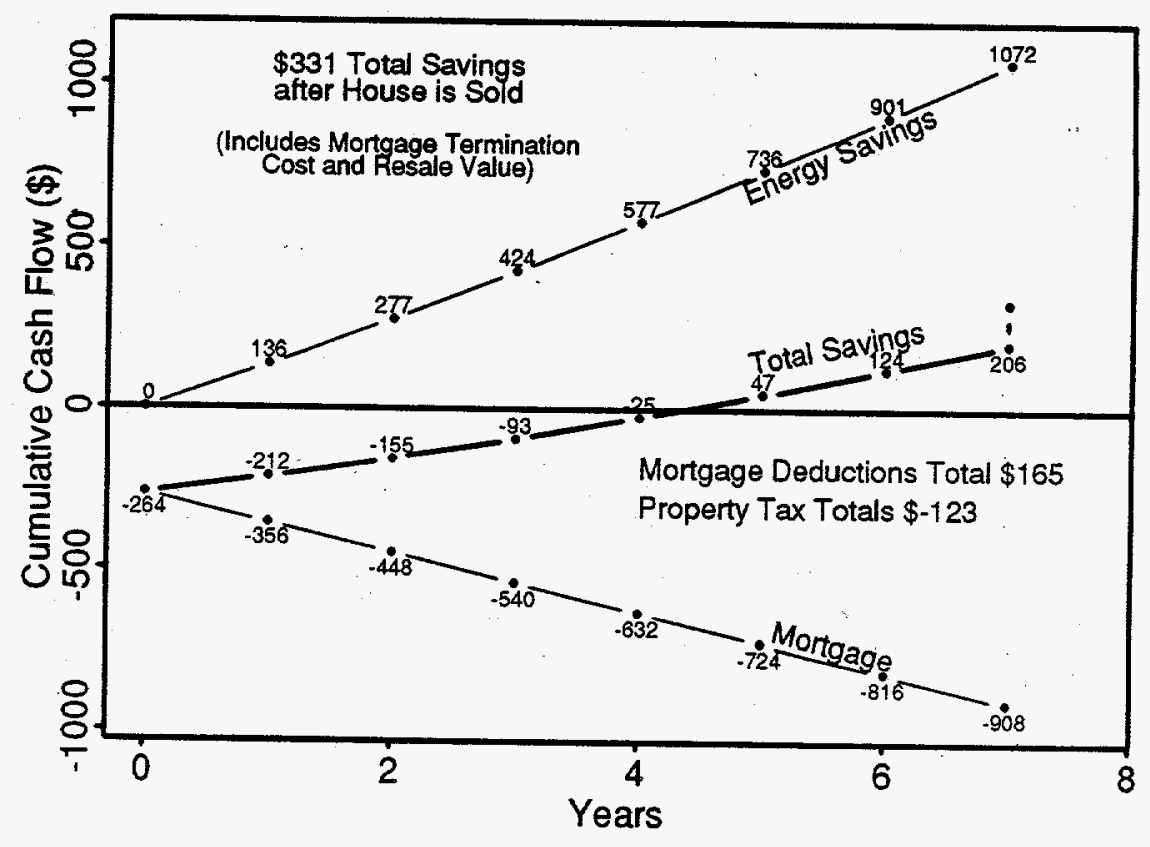

Figure 3. Typical Cash Flow for the First Owner of a Single-Family House

The cash flow from increased efficiency for future owners is even more favorable than the cash flow for the first owner because depreciation causes the purchase cost to decrease, and likely future fuel cost increases cause energy cost savings to increase.

The number of buyers impacted by the increased first cost can be estimated. The National Association of Home Builders (NAHB) estimated that a cost increase of $\$ 1680$ required an additional $\$ 570 /$ year in buyer income and disqualified $2.5 \%$ of the potential home buyers (Consumers' Research 1991). For New Brunswick with natural gas heating, this was scaled back to the estimated increase in first cost, $\$ 1250$, producing an estimate that the energy-efficiency standards would require an additional \$424 in family income and disqualify approximately $1.9 \%$ of the potential new home buyers. However, the $98.1 \%$ who will not be affected in the mortgage qualification process would be better off. The minimal cost increase for the buyer of a multifamily unit should not affect the mortgage qualification process. This calculation assumes that no credit is given in the mortgage process for reduced homeowner expenses resulting from a reduction in energy costs and that the home buyer does not cut expenses elsewhere in the cost of the dwelling.

All the results shown to this point are over the short term. An economic measure of long-term investments that is commonly used is the life-cycle cost. The life-cycle cost is the present value of all costs and benefits, with future costs and/or benefits discounted to account for the lower value 
of money in the future relative to the present. With a 30 -year period of analysis and a $4.0 \%$ real discount rate, life-cycle cost savings from compliance with the 1993 MEC vary from $\$ 220$ in Camden to $\$ 650$ in Sparta.

\section{Conclusions}

The 1993 MEC requires more stringent energy-efficiency levels than ASHRAE Standard 90A-1980. Compliance with the MEC was estimated to increase first costs by $\$ 1028$ to $\$ 1564$ for single-family houses and $\$ 121$ to $\$ 223$ for multifamily units. The time when the homeowner realizes net cash savings (net positive cash flow) for single-family houses built in accordance with the MEC was 1 to 5 years. Impacts on the buyer of a multifamily dwelling are very minimal as very little additional investment in energy efficiency is required for compliance with the MEC. 


\section{Analysis Tool}

This analysis utilized the energy database in the Automated Residential Energy Standard (ARES) program. The ARES software is a computer program developed for DOE that contains an economic methodology for residential energy-efficiency decisions (Lortz and Taylor 1989). Given a set of fuel-price, financial, economic, and energy-efficiency measure cost parameters for a building at a specific location, ARES identifies the economic impacts of incremental improvements in energy efficiency. ARES considers both space heating and cooling, and is designed specifically for residential energy-efficiency analyses.

In addition to an economic analysis model, ARES incorporates an energy database produced by a simulation model, allowing it to estimate the energy use for a specific selection of insulation and window measures. The energy usage associated with each combination of measures becomes an input to the ARES economic analysis. The incorporation of an energy simulation in ARES removes the requirement for doing separate building energy simulations. The ARES energy simulation is a parameterization of a large database of DOE-2 simulations (DOE 1989a) (DOE-2 is a sophisticated energy-analysis software commonly used to estimate building energy consumption). 



\section{Financial, Economic, and Fuel-Price Parameters}

In this section, the financial, economic, and fuel-price-parameter values necesșary for the cost/benefit analysis of the 1993 MEC are specified, justified, and documented. Most of the financial, economic, and fuel-price parameters required for input to this analysis are summarized below. These parameters are used to calculate the costs and benefits from the homeowner's perspective.

- new home mortgage parameters

- mortgage interest rate $(8.0 \%)$

- points and loan fees (1.6\% of the mortgage amount)

- loan term (30 years)

- down payment (20\% for single-family, $10 \%$ for multifamily)

- other rates and economic parameters

- marginal federal plus state income tax rates (30\% for single-family, $17 \%$ for multifamily)

- property tax $(1.7 \%)$

- residential fuel prices by city.

In choosing the parameters for the analysis, the intent was to identify and document the best source available for each parameter. Most of the parameter values are commonly reported statistics and are traceable to other published sources. Some of the data were provided by the New Jersey Office of Community Affairs. It should be noted that some of the parameter values vary across time, locations, markets, institutions, circumstances, and/or individuals.

Financial Parameters

Because most home buyers obtain a mortgage, the economic analysis accounts for a mortgage. A mortgage interest rate of $8.0 \%$ was selected for this analysis--this is approximately equal to recent rates (NAHB 1995) and long-term average rates (OTS 1991). Points and loan fees were assumed to be $1.6 \%$ of the mortgaged amount; this is based on long-term U.S. Office of Thrift Supervision historical real averages using 1963-1991 data (OTS 1991). The up-front mortgage costs were assumed to be split equally between points (tax deductible) and loan fees (not tax deductible).

The 30-year mortgage term is the most typical; therefore, $\mathbf{3 0}$ years was the loan term for this analysis.

A down payment of $20 \%$ of the mortgage amount was used for the singlefamily home buyer. A down payment of $10 \%$ was used for the multifamily unit to represent the lower down payment commonly paid by a financially limited first-time home buyer. 


\section{Inflation Rate}

Property Tax Rate

Income Tax Rate

Fuel Prices
Private mortgage insurance is normally required for loans without large down payments. Based on data provided by a mortgage company, the NAHB (1992)-developed data, and various types of loans and down payments commonly available, average private mortgage insurance costs were calculated. Private mortgage insurance was included as a non-taxdeductible cost to the home buyer, fixed at $3.5 \%$ of the mortgage loan amount, and included in the mortgage payments. It should be noted that many home buyers do not need private mortgage insurance.

An inflation rate of $3.9 \%$ is used to account for the expected increase in future fuel costs. This rate is from DOE's Energy Information Administration and is equal to the average forecast of four other sources (EIA 1993). Note that, over the short term, the impact of the inflation rate is small.

For this analysis, there was assumed to be a property tax of $1.7 \%$ of the dwelling's value. Therefore, the homeowner must pay $1.7 \%$ of the increase in first costs from the higher levels of energy efficiency resulting from compliance with the 1993 MEC. This typical tax rate for New Jersey was determined from an article in Money (1992).

The marginal income tax rate paid by the homeowner determines the value of the mortgage tax deduction. The homeowner is assumed to itemize deductions, which is most common. For the single-family home buyer, the marginal income tax rate was assumed to be $28 \%$. Because the multifamily scenario focuses on the low- to medium-income home buyer, the marginal income tax rate was assumed to be $15 \%$. Accounting for a state income tax rate of $2 \%$ (Conner and Lucas 1994), the total income tax rate used for the single-family and the multifamily analyses was $30 \%$ and $17 \%$, respectively.

From the consumer's perspective, the energy cost savings from changes in energy-efficiency levels are driven by marginal fuel prices, which may not equal average fuel prices. For example, utilities often charge a lower rate per kilowatt hour of electricity for additional consumption beyond some minimum threshold--the marginal rate is this lower rate. Because energy saved by complying with the 1993 MEC will be the marginal rate, marginal fuel prices were used in the analysis. Residential energy prices for natural gas were obtained from the American Gas Association Rate Service (AGA 1994). Electricity prices were obtained from the Public Service Electric and Gas Company in March 1995. These electricity rates are for consumption above $600 \mathrm{kWh} / \mathrm{mo}$, which should occur in most dwellings during most months. The heating fuel oil price was provided by the New Jersey Department of Community Affairs. The fuel prices used in the analysis are shown in Table 5. 
Table 5. Fuel Prices by City ${ }^{(a)}$

\begin{tabular}{|c|c|c|c|c|}
\hline \multirow[b]{2}{*}{ City } & \multirow{2}{*}{$\begin{array}{l}\text { Natural Gas } \\
\text { (\$/therm) }\end{array}$} & \multirow{2}{*}{$\begin{array}{c}\text { Fuel Oil } \\
\text { (\$/gal) }\end{array}$} & \multicolumn{2}{|c|}{ Electricity $(\$ / \mathrm{kWh})$} \\
\hline & & & Heating & Cooling \\
\hline Camden & 0.604 & 0.85 & 0.106 & 0.127 \\
\hline New Brunswick & 0.604 & 0.85 & 0.106 & 0.127 \\
\hline Somerville & 0.604 & 0.85 & 0.106 & 0.127 \\
\hline Sparta & 0.612 & 0.85 & 0.106 & 0.127 \\
\hline
\end{tabular}





\section{Energy-Efficiency Measures}

\author{
Thermal-Envelope \\ Energy-Efficiency \\ Measures
}

The analysis to determine the cost effectiveness of the MEC in New Jersey requires information on the costs of insulation and window measures to meet ASHRAE Standard 90A-1980 and the 1993 MEC. This section primarily documents the characterization of the measures used in the analysis, including the thermal ratings (R-values for the ceilings, above- grade opaque walls, and basement walls; U-values for windows); costs; and some of the construction assumptions.

This economic analysis considers the cost effectiveness of the MEC thermal-envelope requirements. The envelope components considered in the analysis are ceilings, above-grade opaque walls, windows, doors, and basements with wall insulation (basements are the most common foundation type in New Jersey residences). Table 6 shows insulation levels and window types corresponding to ASHRAE 90A-1980 and 1993 MEC compliance for the single-family and multifamily dwellings.

The MEC and ASHRAE Standard generally specify thermal-envelope requirements in terms of overall $U$-value, which is called the $U_{o}$-value. A U-value is the inverse of the $R$-value, and a lower $U$-value represents higher energy efficiency. The $U_{0}$-value accounts for all materials in the component, including gypsum board, framing, insulation, and siding. Components include ceilings, above-grade walls, and various foundation types. The MEC does not specify window, door, or opaque wall thermal requirements individually, but rather specifies gross wall $\mathrm{U}_{\mathrm{o}}$-value requirements. Both the MEC and ASHRAE Standard requirements vary by HDD, though no variation in ASHRAE requirements was assumed across the four cities because New Jersey uses the ASHRAE Standard requirements at $5500 \mathrm{HDDs}$ for the entire state.

It should be noted that compliance with the $1993 \mathrm{MEC}$ can be based on meeting individual component $U_{0}$-value requirements, an equivalent overall building $\mathrm{U}_{0}$-value (as was done for this analysis), or an energy equivalent based on a whole-building energy analysis. Thus, a number of alternative combinations would lead to compliance for any particular dwelling. Builders would be free to use any type of construction that complied with the MEC component $U_{0}$-value, overall $U_{0}$-value, or energy-based performance requirements. For this analysis, complying packages of measures shown in Table 6 were selected utilizing software known as "MECcheck ${ }^{\text {nu }}$ (PNL 1995), which notifies the user if a set of insulation and window measures complies with the MEC and allows tradeoffs across all building components. Note that Table 6 includes some tradeoffs allowed in Section 502.1.1 in the MEC. For example, in Somerville, the R-30 ceiling insulation will not meet the roof/ceiling $\mathrm{U}_{\mathrm{o}}$-value requirement shown on page 74 of the MEC. This is compensated for, however, by the energy-efficient windows. 
Table 6. Energy-Efficiency Measures for ASHRAE Standard 90A-1980 and 1993 MEC

\begin{tabular}{|c|c|c|c|c|}
\hline & $\begin{array}{l}\text { Ceiling } \\
\text { Insulation }\end{array}$ & $\begin{array}{c}\text { Wall } \\
\text { Insulation }\end{array}$ & Window Type & $\begin{array}{l}\text { Basement } \\
\text { Insulation }\end{array}$ \\
\hline $\begin{array}{l}\text { ASHRAE Standard } \\
90 \mathrm{~A}-1980\end{array}$ & R-30 & $\mathrm{R}-11$ & $\begin{array}{l}\text { Double vinyl or } \\
\text { wood }\end{array}$ & None \\
\hline \multicolumn{5}{|l|}{$1993 \mathrm{MEC}$} \\
\hline $\begin{array}{l}\text { Camden } \\
\text { Single family }\end{array}$ & R-30 & R-13 batt & $\begin{array}{l}\text { Double vinyl or } \\
\text { wood, with low-E }\end{array}$ & $\mathrm{R}-5,4 \mathrm{ft}$ deep \\
\hline Multifamily & $R-30$ & $\mathrm{R}-11$ batt & $\begin{array}{l}\text { Double vinyl or } \\
\text { wood, with low-E }\end{array}$ & R-0 \\
\hline $\begin{array}{l}\text { New Brunswick } \\
\text { Single family }\end{array}$ & $R-38^{(a)}$ & $\mathrm{R}-13$ batt & $\begin{array}{l}\text { Double vinyl or } \\
\text { wood, with low-E }\end{array}$ & $\mathrm{R}-5,4 \mathrm{ft}$ deep \\
\hline Multifamily & $\mathrm{R}-30$ & R-11 batt & $\begin{array}{l}\text { Double vinyl or } \\
\text { wood, with low-E }\end{array}$ & R-0 \\
\hline $\begin{array}{l}\text { Somerville } \\
\text { Single family }\end{array}$ & R-30 & R-13 batt & $\begin{array}{l}\text { Double vinyl or } \\
\text { wood, with low-E }\end{array}$ & $\begin{array}{l}\mathrm{R}-10,4 \mathrm{ft} \\
\text { deep }\end{array}$ \\
\hline Multifamily & $R-30$ & R-11 batt & $\begin{array}{l}\text { Double vinyl or } \\
\text { wood, with low-E }\end{array}$ & $\mathbf{R}-0$ \\
\hline $\begin{array}{l}\text { Sparta } \\
\text { Single family }\end{array}$ & R-30 & $\begin{array}{l}\mathrm{R}-13 \text { batt }+ \\
\mathrm{R}-4 \text { rigid }\end{array}$ & $\begin{array}{l}\text { Double vinyl or } \\
\text { wood, with low-E } \\
\text { and argon }\end{array}$ & $\begin{array}{l}\mathrm{R}-10,4 \mathrm{ft} \\
\text { deep }\end{array}$ \\
\hline Multifamily & $\mathrm{R}-38$ & R-11 batt & $\begin{array}{l}\text { Double vinyl or } \\
\text { wood, with low-E }\end{array}$ & R-0 \\
\hline
\end{tabular}

Combinations of measures other than those shown in Table 6 could also be selected. For one example in Camden, New Brunswick, and Somerville for the multifamily unit, if the walls and ceilings have R-11 and R-38 insulation, respectively, low-E coatings are not needed on the windows. Additionally, if the heating, ventilating, and air-conditioning (HVAC) equipment efficiencies are above the minimums assumed in this analysis (i.e., the minimums allowed by law), reductions in the energy efficiency of the envelope levels may be possible.

Insulation and Window Measure Costs
Having established insulation and window measures for compliance with ASHRAE Standard 90A-1980 and the 1993 MEC, the next step was to determine construction costs for each of these measures. The costs of. 


\section{Ceilings}

interest are those for the improvement in energy efficiency to move from the levels needed for ASHRAE compliance to the levels needed for MEC compliance. All costs in the tables in this section represent retail costs to the home buyer/owner. These costs include materials, installation, and markups for overhead and profit. Cost data were modified to account for higher construction costs in New Jersey, using location factors reported by Means (1994). These factors increased national prices by $4 \%$ for Camden, $8 \%$ for New Brunswick and Somerville, and 7\% for Sparta (the multipliers were not provided in Means [1994] for Sparta, so the cost adjustment for nearby Dover, New Jersey was used). These location adjustments are not included in the costs shown in the following sections. Costs from older sources were inflated to current conditions based on the residential construction cost inflation rate (DOC 1992, 1995).

Component $\mathrm{U}_{0}$-values are also presented in the following sections. $\mathrm{U}_{0}$-values affect compliance with ASHRAE Standard 90A-1980 and the $1993 \mathrm{MEC}$ and closely relate to energy use. The $U_{\mathrm{o}}$-values-used here were determined using material thermal properties and calculation techniques recommended by ASHRAE (1989). Window $\mathrm{U}_{\mathrm{o}}$-values were obtained from tested window data.

Ceilings were assumed to have an attic space; vaulted ceilings/roofs were not considered. Dwellings with vaulted ceilings may have lower levels of insulation in the vaulted section with slightly higher levels elsewhere. No skylights were assumed. Cost data for ceiling-insulation levels and construction assemblies were obtained from two national sources:

- Means Residential Cost Data-1995 (Means 1994)

- 1995 National Construction Estimator (Craftsman 1994)

The costs are for regular-density fiberglass batt insulation and only R-30 and R-38 were used in the calculation of costs and benefits. Table 7 shows the $U_{0}$-values and costs for roof/ceiling-insulation $R$-values used in this analysis.

Table 7. Ceiling $U_{0}-$ Values and Costs

\begin{tabular}{|c|c|c|}
\hline Nominal R-Value & Ceiling $\mathrm{U}_{\mathrm{o}}$-Value & $\begin{array}{c}\text { Cost Relative to } \\
\mathrm{R}-11\left(\$ / \mathrm{ft}^{2}\right)\end{array}$ \\
\hline \hline $\mathrm{R}-30$ & 0.0353 & 0.36 \\
$\mathrm{R}-38$ & 0.0300 & 0.52 \\
\hline
\end{tabular}

Walls

The wall insulation assumed for ASHRAE Standard 90A-1980 compliance in New Jersey was R-11 insulation in a 2 by 4 16-in. on-center framed wall with plywood sheathing. Compliance with the 1993 MEC was achieved by a combination of R-11 or R-13 wall insulation and, in one instance, 
foam sheathing insulation. Table 8 shows the wall-insulation measures, $\mathrm{U}_{\mathrm{o}}$-values, and cost increments used in this analysis in order of decreasing $\mathrm{U}_{0}$-value.

The addition of foam sheathing is a commonly available option, as evidenced by the Means cost data (Means 1994), the Energy Crafted Homes data (Fryer and Schalch 1992), Residential Construction Demonstration Project data (Barnett and Thor 1990), and Builder Magazine (NAHB 1991a). Walls with rigid foam insulation lack structural support and, therefore, need let-in corner bracing. These bracing costs were obtained from Means (1994) and were $\$ 0.13 / \mathrm{ft}^{2}$ of wall area for 16-in. on-center construction. Walls with plywood at the corners can be used instead of the let-in bracing (plywood corner bracing was assumed in the wall U-value calculations). The Means data indicated the cost of the R-4 insulation including corner bracing is lower than the wood-based sheathing material (such as oriented strand board) it would replace. However, this potential cost reduction may not occur if MEC compliance is required, so, to be conservative, the incremental cost of the $R-4$ insulation was assumed to be zero.

Table 8. Wall $\mathrm{U}_{\mathrm{o}}-$ Values and Costs

\begin{tabular}{|c|c|c|c|}
\hline $\begin{array}{c}\text { Nominal Batt } \\
\text { Insulation R-Value }\end{array}$ & $\begin{array}{c}\text { Rigid Insulation } \\
\mathrm{R}-\text { Value }\end{array}$ & $\begin{array}{c}\mathrm{U}_{\mathrm{o}} \text {-value } \\
\text { of Wall }\end{array}$ & $\begin{array}{c}\text { Cost Relative to } \\
\mathrm{R}-11\left(\$ / \mathrm{ft}^{2}\right)\end{array}$ \\
\hline 11 & 0.83 & 0.0825 & 0.00 \\
13 & 0.83 & 0.0747 & 0.07 \\
13 & 4 & 0.0593 & 0.07 \\
\hline (a) The R-value of 0.83 is for plywood sheathing. \\
\hline
\end{tabular}

Windows
Window cost data were obtained in a manner and from sources different than the insulation cost data. The most important aspect of collecting window cost data is to correctly associate a cost and a $U_{0}$-value. Obtaining a cost-versus-energy-efficiency relationship is more difficult for windows because window costs are greatly affected by nonenergy characteristics, such as appearance. Obtaining window-efficiency costs is made more difficult by the relatively rapid changes in window technology and energyefficiency costs. In particular, vinyl framing, low-emissivity (low-E) coatings, and argon-filled windows are rapidly penetrating the market and are dropping in price.

Two sources of window cost data were judged to be the best available. The first was a survey of nine Pacific Northwest window manufacturers for the Washington State Energy Office (Byers 1990). The other source of window cost data was the work done for the California Energy Commission by Eley Associates (1991). A number of reasons dictated the use of these two sources. Foremost was costs for a fairly extensive set of window types were available from multiple manufacturers in both of these sources. (In all 
cases, there were three or more manufacturers from each of the two sources for each window improvement option of interest.) The data included new energy-efficient technologies, such as vinyl frames, low-E surfaces, and argon gas.

The examination of windows currently in the market from an energyefficiency standpoint showed that the range of costs and efficiencies for the most cost-effective windows could be represented with incremental prices for only a few energy-related features. The window assumed for compliance with ASHRAE Standard 90A-1980 was a double-paned, vinylor wood-framed window. The incremental changes in windows needed for costing were the addition of low-E coating and the addition of argon gas to double-paned windows. To isolate cost changes for improved energy efficiency, the cost changes for incremental window improvements (such as adding low-E) were determined separately for each manufacturer, so that cost changes were not aggregated across manufacturers until after the cost changes had been identified for each manufacturer. Examining window improvements by manufacturer tended to avoid the large variation in other window characteristics that affect price in intermanufacturer comparisons. The costs for any given incremental thermal improvement were assumed to be constant regardless of other thermal characteristics. For example, the costs of adding a low-E coating to vinyl- and wood-framed windows should be very similar. Further, the Washington and California costs were averaged for each window feature. The window costs in both the Washington and California data were the total costs as sold by the manufacturer to mid-sized builders. Installation costs and contractor profit were added to these costs.

Current costs for low-E coatings were difficult to establish because of recent technology improvements. For this reason, the Washington (Byers 1990) or California (Eley 1991) cost data were not used; instead, an estimated cost that was lower was used. In the last few years, there has been a change in the commercially available low-E technologies. Of most interest here is the new "hardcoat" low-E coating, which is both better in performance and lower in price than older "hardcoat" technologies. This new low-E technology has begun to reach the market and was assumed to be the most cost-effective type of coating. The cost of the new low-E coatings to the glass manufacturer is low, approximately $\$ 0.50 / \mathrm{ft}^{2}$ (Gerhardinger and Flagg 1992). Based primarily on this manufacturer's cost, the retail cost (including overhead and profit) of the new low-E coating was estimated to be $\$ 1.00 / \mathrm{ft}^{2}$ to the consumer.

Window $\mathrm{U}_{0}$-values had to be established for the types of windows examined here. The window types used in the analysis are shown in Table 9. The $\mathrm{U}_{\mathrm{o}}$-values are based on median values of windows given by the National Fenestration Rating Council (NFRC 1994). For each of the three window types included in this analysis, there are at least 98 Council-rated products available. $U_{0}$-values for available windows vary considerably about these median values. 
Table 9. Window $U_{0}-$ Values and Costs

\begin{tabular}{|l|c|c|}
\hline \multicolumn{1}{|c|}{ Window/Frame Type } & $\begin{array}{c}\text { Window } \\
\mathrm{U}_{\mathrm{o}} \text {-Value }\end{array}$ & $\begin{array}{c}\text { Cost Relative to Double } \\
\text { Vinyl or Wood }\left(\$ / \mathrm{ft}^{2}\right)\end{array}$ \\
\hline \hline Double vinyl or wood & 0.50 & 0 \\
Add low-E coating & 0.38 & 1.00 \\
Add low-E coating and argon & 0.34 & 2.10 \\
\hline
\end{tabular}

Doors

\section{Basement Walls}

Steel doors with U-values of 0.19 (ASHRAE 1989) were assumed for both the house complying with ASHRAE Standard 90A-1980 and the house complying with the 1993 MEC. Because no change in doors was assumed, the cost of the doors is not relevant in this analysis.

The foundation type assumed in this analysis was a fully below-grade unfinished basement. Insulating the exterior of the basement wall with rigid foam insulation was assumed for compliance with the 1993 MEC for the single-family house (the interior side of the basement could be insulated instead). The cost of insulating the exterior of a basement wall with rigid polystyrene insulation (R-5 or R-10) included a protective stucco coating and was obtained from Means (1994). Costs and $U_{0}$-values for basement walls are shown in Table 10.

Table 10. Basement $U_{0}-$ Values and Costs

\begin{tabular}{||l|c|c||}
\hline \multicolumn{1}{|c|}{ Insulation Type } & $\mathrm{U}_{\mathrm{o}}$-Value & $\begin{array}{c}\text { Cost Relative to No Insulation } \\
\text { (\$/linear } \mathrm{ft} \text { of perimeter) }\end{array}$ \\
\hline \hline None & 0.1514 & 0 \\
R-5, $4 \mathrm{ft}$ deep & 0.088 & 4.86 \\
R-10, $4 \mathrm{ft}$ deep & 0.071 & 6.10 \\
\hline
\end{tabular}

Compliance with the $1993 \mathrm{MEC}$ can also be achieved by insulating the basement ceiling. Insulating the basement walls is a more expensive method of complying with the MEC than insulating the basement ceiling. However, insulating the basement walls has the advantage of keeping the basement warmer. If the homeowner wishes to use the basement as practical living space (such as a family room), the basement-wall insulation will greatly improve comfort. If the basement is to be finished, the inside of the basement wall can be insulated instead of the outside. Also, if the basement walls are insulated, ducts located in the basement do not have to be insulated (this potential cost savings was not accounted for in the analysis). 
Prototype Dwellings
A survey of new single-family houses (NAHB 1991b) indicated two-story houses were most common in New Jersey, with split-level and one-story less common. This same survey indicated the average finished floor area for new houses in New Jersey was $2277 \mathrm{ft}^{2}$.

A two-story, single-family house, with dimensions of $28 \mathrm{ft}$ wide and $40 \mathrm{ft}$ long, with a conditioned floor area of $2240 \mathrm{ft}^{2}$, was assumed in this analysis: 8-ft-high ceilings; ceiling area (bordering the unconditioned attic) of $1120 \mathrm{ft}^{2}$; gross exterior above-grade wall area of $2176 \mathrm{ft}^{2}$; and basement wall area of $1088 \mathrm{ft}^{2}$. A total door area of $56 \mathrm{ft}^{2}$ (approximately 3 doors) was used (Johnson 1987).

Windows have much higher $\mathrm{U}_{0}$-values than opaque walls. Therefore, the amount of window area has a major effect on the gross wall $U_{0}$-value and, therefore, affects compliance with the 1993 MEC. Houses with high window areas will need greater levels of energy efficiency to comply with the MEC. Obtaining data on window area in new single-family housing proved difficult. An older source (NAHB 1981) reported a national average of $10.3 \%$ in 1980 . One source (Johnson 1987) indicated a national average window area of approximately $12 \%$ of the floor area. The most current published source identified (Mundy 1991) reported an estimated average of $410 \mathrm{ft}^{2}$ of flat glass sold per new house. Note that this is the area for the glass, not the window; double-pane glazing requires twice the glass needed for single glazing. In a personal communication, Mr. Eric J. Mundy, The Freedonia Group, Inc., Cleveland, Ohio, updated this value for 1992 . He estimated that the average for 1992 was $430 \mathrm{ft}^{2}$ per dwelling. Accounting for double-paned windows, storm windows, and storm doors, an average of approximately $220 \mathrm{ft}^{2}$ of window area in new houses was estimated (AAMA 1992). This corresponds to a window area of approximately $11 \%$ to $12 \%$ of the floor area for the prototype (or a wall with $12 \%$ to $13 \%$ glazing). A second method was used to try to estimate the window area in new construction. Mundy (1991) reported 595 million $\mathrm{ft}^{2}$ of glass sold in 1990 in the new housing market. Using data on new housing construction (DOC 1992), the average window-to-floor area (across all types of residential housing units) was estimated to be approximately $13 \%$ to $14 \%$.

All of the sources for window areas indicated a window-to-floor area ratio of $14 \%$ or less; however, this is an average value. The distribution of window areas in new housing varies around this average. For the singlefamily analysis, a window area of $14 \%$ of the wall area $\left(305 \mathrm{ft}^{2}\right.$, or $13.6 \%$ of the conditioned floor area) was assumed.

The multifamily prototype was assumed to be a $1300-\mathrm{ft}^{2} 2$-story townhouse in a 6-unit building. Each unit was assumed to be 20 by $32.5 \mathrm{ft}$, with the dimensions of the 6-unit building being 120 by $32.5 \mathrm{ft}$. Assuming 8-ft-high ceilings, the average gross exterior wall area per unit is $813 \mathrm{ft}^{2}$. 


\section{Heating, Ventilating, and Air-Conditioning Specifications}

As with a single-family prototype, the most important multifamily prototype assumption in terms of 1993 MEC compliance is the fraction of wall area that is windows and doors. Because multifamily units often have relatively little exterior wall area, the percentage of the wall that is windows tends to be higher than that for single-family houses. The prototype is assumed to have a window-to-wall area percentage of $20 \%$. This gives $163 \mathrm{ft}^{2}$ of window area, equivalent to $12.5 \%$ of the floor area. The door area is assumed to be $40 \mathrm{ft}^{2}$, which equates to approximately 2 exterior doors.

The heating fuel types and equipment assumed in this analysis are shown in Table 11. Central air conditioning and an air-ducted distribution system were assumed in all four cities.

The minimum efficiency of residential HVAC equipment and water-heating equipment are set by mandatory requirements in the National Appliance Energy Conservation Act of 1987. Because of this law, the HVAC and water-heating efficiency requirements in the $1993 \mathrm{MEC}$ are superseded and will have no impact. The heating and cooling equipment efficiencies in this analysis were set at the minimum levels allowed by the Act as shown in Table 11.

Table 11. Equipment Efficiencies Used in This Analysis

\begin{tabular}{|l|l|}
\hline \multicolumn{1}{|c|}{ System } & \multicolumn{1}{c|}{ Efficiency } \\
\hline \hline Natural gas furnace & 0.78 annual fuel utilization efficiency (AFUE) \\
Oil furnace & 0.78 AFUE \\
Electric heat pump & 6.8 heating seasonal performance factor \\
Air conditioner ${ }^{(a)}$ & 10.0 seasonal energy-efficiency ratio \\
\hline (a) The efficiency shown is for air conditioners with split systems. \\
\hline
\end{tabular}

The effect of heating and cooling equipment downsizing is included automatically in this analysis by the ARES software (DOE 1989b). Smaller heating or cooling loads reduce required equipment capacities, and the equipment cost declines accordingly. This equipment cost change is small.

Recent research and field measurements have shown duct losses to be a major inefficiency. A single distribution-efficiency factor for air-ducted systems was used in this analysis. This value was determined by reviewing relevant work from recognized experts in the building science technical community and then contacting the respective authors and discussing their findings in light of the objective. These sources (given in Conner and Lucas 1994) were in reasonable agreement, and average values of $75 \%$ duct efficiency (i.e., $25 \%$ loss) were used in this analysis. 


\section{References}

American Architectural Manufacturers Association (AAMA). 1992. Study of the Residential Window and Skylight Markets. Palatine, Illinois.

American Gas Association (AGA). 1994. Rate Service. Arlington, Virginia.

American Society of Heating, Refrigerating, and Air-Conditioning Engineers, Inc. (ASHRAE). 1980. ASHRAE Standard 90A-1980: Energy Conservation in New Building Design. Atlanta, Georgia

American Society of Heating, Refrigerating, and Air-Conditioning Engineers, Inc. (ASHRAE). 1989. ASHRAE Handbook, 1989 Fundamentals Volume. Atlanta, Georgia.

Barnett, C., and P. Thor. 1990. .Construction Cost Analysis for the Residential Construction Demonstration Project - Cycle II. Bonneville Power Administration, Portland, Oregon.

Building Officials \& Code Administrators (BOCA $\left.{ }^{\oplus}\right)$. 1993. The BOCA National Energy Conservation Code/1993. Country Club Hills, Illinois.

Byers, D. 1990. The Cost of Energy Efficient Windows in Washington. WAOENG \#89-61, Washington State Energy Office, Olympia, Washington.

Conner, C. C., and R. G. Lucas. 1994. Technical Support Document for Proposed Revision of the Model Energy Code Thermal Envelope Requirements. PNL-9400, Pacific Northwest Laboratory, Richland, Washington.

Consumers' Research. September 1991. "The Effect of Higher Prices On Housing Affordability." p. 12.

Council of American Building Officials (CABO). 1993. Model Energy Code, 1993 Edition. Falls Church, Virginia.

Craftsman Book Company (Craftsman). 1994. 1995 National Construction Estimator. Carlsbad, California. .

Eley Associates (Eley). 1991. Volume 1: Low-Rise Residential Confidence and Sensitivity Study, Life-Cycle Cost Analysis. San Francisco, California.

Energy Information Administration (EIA). 1993. Annual Energy Outlook. DOE/EIA-0383(93), U.S. Department of Energy, Washington, D.C. 
Fryer, L., and N. Schalch. 1992. "Development and Implementation of a Multi-Utility Residential New Construction Program: The Energy Crafted Home Program." In Volume 5 - Utility Programs - Proceedings of the ACEEE 1992 Summer Study on Energy Efficiency in Buildings, pp. 63-73. American Council for an Energy-Efficient Economy, Washington, D.C.

Gerhardinger, P. F., and A. M. Flagg. 1992. "Energy Conservation in Existing Buildings Using High Performance Pyrolytic Low-E Glass." In Volume 1 - Commercial Technologies: Design and Operation-Proceedings of the ACEEE 1992 Summer Study on Energy Efficiency in Buildings, pp. 81-87. American Council for an Energy-Efficient Economy, Washington, D.C.

Johnson, A. W. 1987. A Preliminary Analysis of Proposal 87-20 (MIMA) to the Model Energy Code. Johnson and Associates, Gaithersburg, Maryland.

Lortz, V. B., and Z. T. Taylor. 1989. Recommendations for Energy Conservation Standards for New Residential Buildings. Volume 2: Automated Residential Energy Standard - User's Guide - Version 1.1. PNL-6878 Vol. 2, Pacific Northwest Laboratory, Richland, Washington.

R. S. Means Company, Inc. (Means). 1994. Means Residential Cost Data-1995. Kingston, Massachusetts.

Money. January 1992. "From Tax Heaven in Alaska to Hell in New York." pp. 74-75.

Mundy, E. 1991. Flat Glass Products and Markets. Business Research Report B269, The Freedonia Group, Inc., Cleveland, Ohio.

National Appliance Energy Conservation Act of 1987, Public Law 100-12, 42 USC 6291 et seq., as amended.

National Association of Home Builders (NAHB). 1981. 1980 Base Case and Feasibility Analysis. NAHB Research Center, Upper Marlboro, Maryland.

National Association of Home Builders (NAHB). 1991a. Builder Magazine. March 1991, p. 146.

National Association of Home Builders (NAHB). 1991b. 1991 NAHB Research Foundation Special Report. NAHB Research Center, Upper Marlboro, Maryland. 
National Association of Home Builders (NAHB). 1992. Profile of the New Home Buyer. Washington, D.C.

National Association of Home Builders (NAHB). 1995. Housing Market Statistics. August 1995. Washington, D.C.

National Fenestration Rating Council (NFRC). 1994. Certified Products Directory. Second Edition. Silver Spring, Maryland.

Pacific Northwest Laboratory. 1995. MECcheck ${ }^{\mathrm{Tx}}$ Software User's Guide Version 2.0. Pacific Northwest Laboratory, Richland, Washington.

U.S. Department of Commerce (DOC). 1992. Survey of Current Business. Washington, D.C.

U.S. Department of Commerce (DOC). 1995. Survey of Current Business. Washington, D.C.

U.S. Department of Energy (DOE). 1989a. Technical Support Documentation for the Automated Residential Energy Standards (ARES), In Support of Proposed Interim Energy Conservation Voluntary Performance Standards for New Non-Federal Residential Buildings. DOE/CE-0274, Vol. 4, Washington, D.C.

U.S. Department of Energy (DOE). 1989b. Technical Support Documentation for the Automated Residential Energy Standards (ARES), In Support of Proposed Interim Energy Conservation Voluntary Performance Standards for New Non-Federal Residential Buildings. DOE/CE-0274, Vol. 2, Washington, D.C.

U.S. Office of Thrift Supervision (OTS). 1991. Rates and Terms on Conventional Home Mortgages. Federal Housing Finance Board, Washington, DC. 


\section{Distribution}

No. of

Copies

OFFSITE

12 U.S. Department of Energy Office of Codes and Standards 1000 Independence Ave. SW

Washington, DC 20585

Attn:J. J. Boulin, EE-43

S. J. Turchen, EE-43 (10)

S. P. Walder, EE-43

\section{ONSITE}

DOE Richland Operations Office

J. K. Schmitz
No. of

Copies

32 Pacific Northwest Laboratory

J. L. Carlson, Program Files (5) . K5-02

L. M. Connell

C. C. Conner

D. R. Conover

B. V. Johnston

L. A. Klevgard

R. G. Lucas (15)

Information Release Office (7)
K5-16

K5-16

BWO

K9-41

K5-20

K5-16

K1-11

K8-50 